teneur en eau, et, en particulier il n'a pas été possible de mettre en évidence des variations de teneur en eau à la suite de condensations superficielles.

$5^{\circ}$ En outre, les expériences décrites ci-dessus permettent de se faire une opinion sur la précision de la méthode de dosage de l'humidité des beurres par dessication à l'étuve à $105^{\circ} \mathrm{C}$., Pour un beurre malaxé normalement, l'écart entre deux dosages sur un même échantillon peut atteindre au maximum $0,3 \%$.

La fig. 2 donne une représentation graphique de ces écarts de dosages en fonction du nombre des échantillons soumis à l'analyse.

$6^{\circ}$ Les expériences ci-dessus prouvent que, tout au moins en ce qui concerne le dosage de l'humidité des beurres, la méthode utilisée par les agents de prélèvement du Service Technique Interprofessionnel du Lait peut être considérée comme satisfaisante.

\title{
SUR L'EMPLOI D'UNE BACTÉRIE THERMOPHILE POUR UN DOSAGE RAPIDE DE LA NISINE (1) \\ PAR
}

\author{
P. RAIBAUD
}

Station Centrale de Microbiologie et Recherches laitières

(Jouy-en-Josas)

$\mathrm{Au}$ cours de recherches entreprises sur le rôle et l'emploi en fromagerie de la nisine produite par certaines souches de Streptococcus lactis, nous avons été amenés à considérer le problème du dosage de cet antibiotique, déjà étudié par différents auteurs [1], [2], [3], [4], [5], [6], [7], [8], sous l'angle de la rapidité et de la simplicité. Dans une étude de ce genre, un procédé permettant une réponse rapide, pour ainsi dire extemporanée, mais cependant suffisamment précise, présente en effet le plus haut intérêt. Or les méthodes dont nous disposons actuellement pour le dosage de la nisine sont toutes des méthodes microbiologiques soumises aux contingences habituelles des techniques bactériologiques : culture entre $30^{\circ}$ et $40^{\circ}$ des organismes-test sur des milieux parfois complexes, stérilité du matériel et asepsie des manipulations.

Pour essayer de pallier ces inconvénients, il nous a paru intéressant d'envisager l'utilisation comme organisme-test d'une bactérie thermophile : une température optima de croissance élevée réalise en effet une sélection naturelle qui, diminuant les risques d'une contamination éventuelle de l'organisme-test par d'autres germes, permet de réduire ou même de supprimer les conditions de stérilité des milieux de culture et l'asepsie des manipulations. D'autre

(1) Annales de Technologie (I.N.R.A.), 1956, no 3, 441. 
part le taux de croissance élevé qui caractérise ces organismes thermophiles assure dans un dosage microbiologique une réponse rapide. Enfin ces bactéries présentent souvent une croissance excellente dans des milieux simples, à base de peptone et de glucides.

\section{MATÉRIEL ET MÉTHODES}

\section{L'organisme-test}

La souche que nous avons utilisée a été isolée selon la technique décrite par Guittoneau [9] : on ensemence 1 gramme environ de fumier ou d'ensilage dans 100 millilitres du milieu suivant :

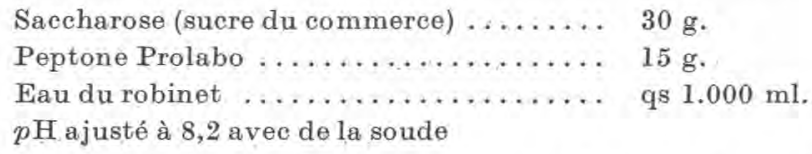

Pour éviter une acidification trop rapide, on sature de carbonate de chaux le flacon destiné à l'isolement. Après 18 heures d'incubation à $68^{\circ}$, un fort dégagement gazeux s'est établi. On fait alors un isolement sur boîtes de Petri contenant le milieu précédent gélosé à $20 \%$ et maintenues à $50-55^{\circ}$, puis un repiquage massif des colonies sur milieu liquide.

La bactérie isolée est un bâtonnet Gram positif, aérobie, saccharolytique. La figure 1 montre que, pendant la phase logarithmique de croissance, la formation d'acide lactique aux dépens du saccharose abaisse le $p \mathrm{H}$ du milieu de culture de $0,25 \pm 0,02$ unités $p \mathrm{H}$ en 5 minutes d'incubation.

La température optima de croissance, $68^{\circ}$, les caractères morphologiques et culturaux, la forme et les conditions d'apparition des spores correspondent à la description donnée par GUITTONNEAU [9] de Thermobacillus tarbellicus.

La croissance au cours des repiquages en milieu liquide est fortement influencée par le $p \mathrm{H}$ initial du milieu, comme le montre la figure 2. On voit l'intérêt d'ajuster ce $p H$ à $8,0-8,2$ pour que se développe ensuite une acidité suffisante dans le milieu de culture.

D'autre part cette bactérie peut manifester au cours de sa croissance une phase de latence dont l'importance est très variable. Elle est considérablement allongée par un simple refroidissement momentané à la température du laboratoire, et plus encore par le séjour à la glacière du milieu ensemencé. Une dose d'inoculation trop faible dans un repiquage est aussi une cause provoquant l'apparition d'une phase de latence prolongée. Il faut en tenir compte au cours des repiquages : dans un milieu ensemencé à $10 \%$ avec une culture en fin de phase logarithmique, n'ayant subi aucun refroidissement, la phase de latence est très courte, et la phase logarithmique commence 
après 30 minutes, environ, d'incubation à $68^{\circ}$. Mais lorsqu'on utilise pour les repiquages une culture conservée à la glacière, la phase de latence peut atteindre 6 heures. Si l'on veut disposer d'une culture bien développée le matin, il faut donc faire incuber le milieu, ensemencé à $10 \%$, au moins pendant 6 heures; pour cela, il suffit de déclencher le chauffage d'un petit bain-marie à $68^{\circ}$ au moyen d'un chrono-relais.

La souche de Thermobacillus tarbellicus se conserve bien à la glacière, en milieu additionné de carbonate de chaux.

\section{Milieu de dosage}

Pour le dosage on utilise le milieu d'isolement sans carbonate. Il est préparé extemporanément, sans filtration ni stérilisation. La figure 3 montre que, si l'on ajoute à un volume déterminé de ce milieu des quantités connues d'acide lactique, les variations du $p \mathrm{H}$ sont les plus importantes entre $p \mathrm{H} 6,8$ et 5,0, et que dans cette zone le $p \mathrm{H}$ est fonction linéaire du logarithme de la concentration en acide lactique.

\section{Matériel}

Nous utilisons des tubes de $18 \times 180$ qu'il n'est pas nécessaire de stériliser avant usage. Il faut, par contre, les laver à la soude selon la technique préconisée par BERRIDGE [7], et les rincer soigneusement à l'eau distillée. L'incubation se fait dans un grand bain-marie pouvant contenir plus de 100 tubes, réglé à $68^{\circ} \pm 0^{\circ} 1$ et convenablement agité pour assurer l'uniformité de la température.

\section{Sources dè nisíne}

Nos essais de dosage ont été effectués à partir de cultures: sur lait de Streptococcus lactis, souche X 13. La culture est portée rapidement - en 5 minutes environ - à l'ébullition pendant 30 secondes, selon la technique de BERRIDGE [8], refroidie aussitôt et centrifugée, Nous avonons dosé la nisine dans le lactosérum ainsi obtenu.

\section{Conduite du dosage}

\section{Principe de dosage}

A des dilutions sroissantes d'un lactosérum dont on veut déterminer la teneur en nisine, on ajoute une culture en phase logarithmique de l'organisme-test. Après un temps d'incubation déterminé, on constate que le $p H$ des tubes a varié proportionnellement à la concentration en nisine, et ceci avec une bonne approximation, à condition de rester dans certaines limites de concentrations. C'est le principe de la méthode de dosage $\mathrm{A}_{2}$ en lait tournesolé de BERRIDGE [8]. 


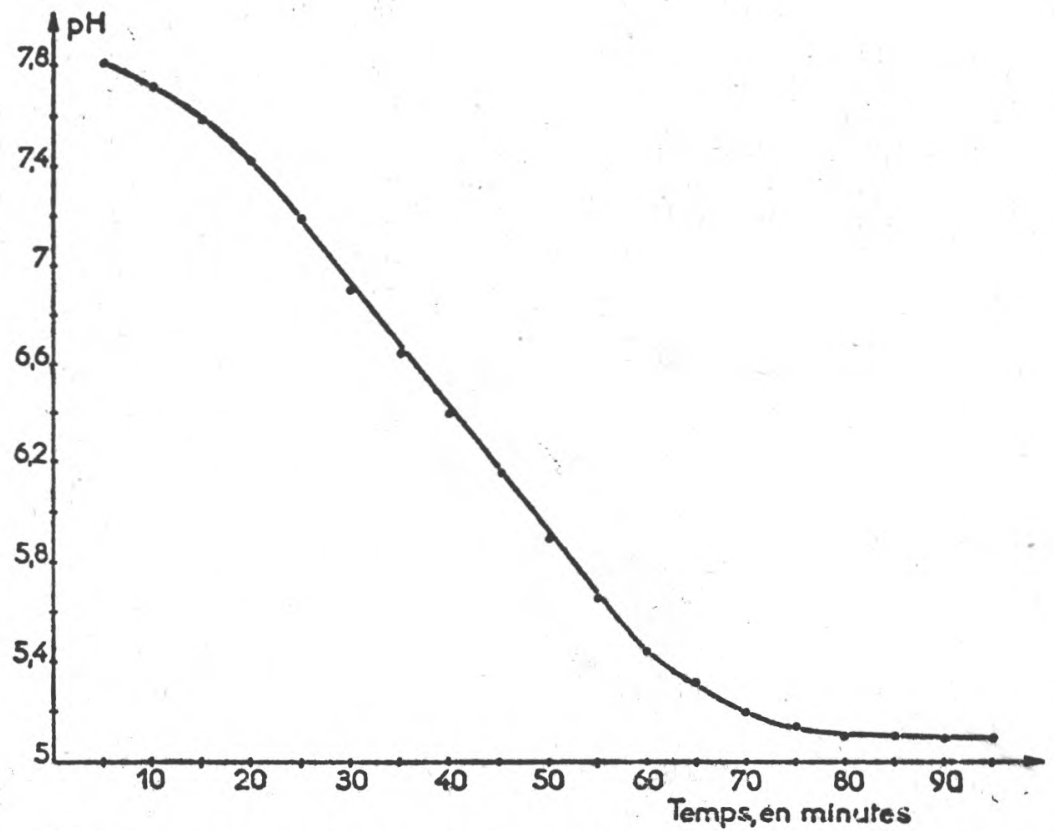

Fig. 1. - Evolution du $p \mathbf{H}$ en fonction du temps dans le milieu de GUITTONNEAU ensemencé avec Thermobacillus tarbellicus. La phase de latence n'est pas figurée.

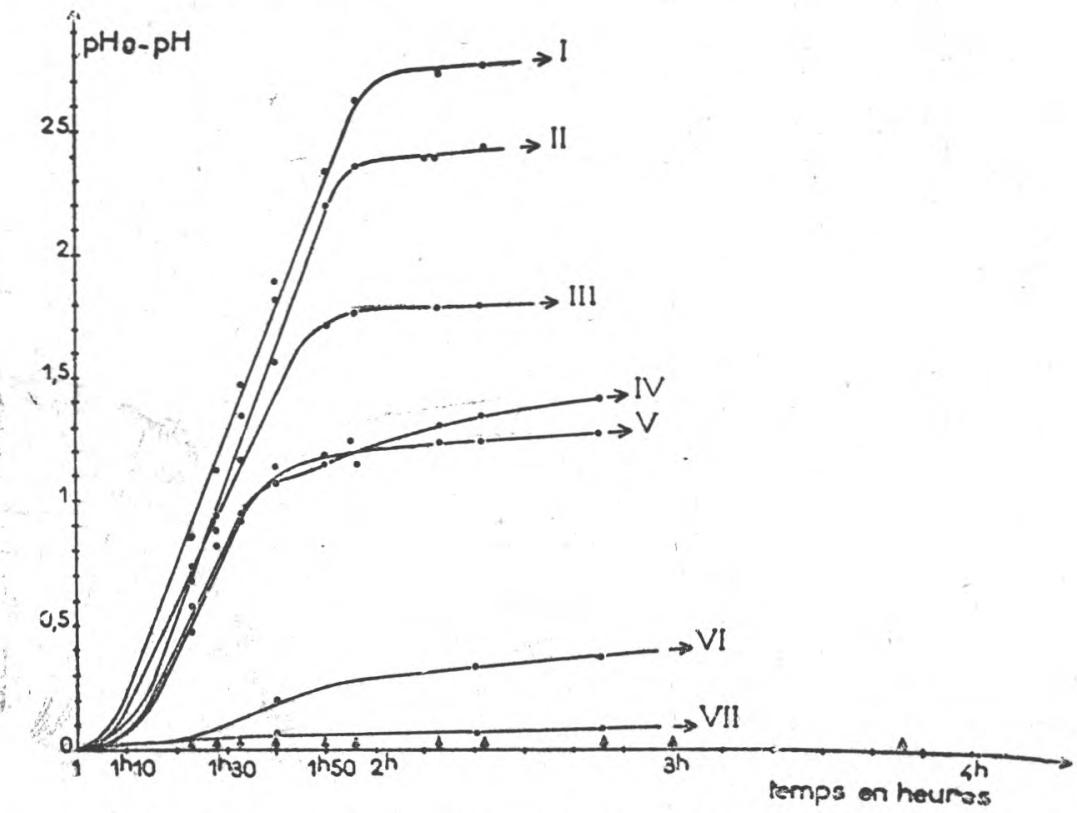

Fig. 2. - Influence du $p \mathrm{H}$ initial $\left(p \mathrm{H}_{0}\right)$ sur l'évolution du $p \mathrm{H}$ en fonction du temps dans le milieu de GUITTONNEAU ensemencé avec Thermobacillus tarbellicus. Courbe I : $p \mathrm{H}_{\mathrm{o}}=8,10$. Courbe II $: p \mathrm{H}_{0}=7,76$. Courbe III : $p \mathrm{H}_{0}=7,24$. Courbe IV $: p \mathrm{H}_{0}=6,94$. - Courbe V : $p \mathrm{H}_{0}=6,78$. Courbe VI $: p \mathrm{H}_{0}=6,58$. - Courbe VII $: p \mathrm{H}_{0}=5,70$. 


\section{Obtention d'une culture en phase logarithmique}

Une culture parvenue en fin de croissance logarithmique est repiquée à $10 \%$ dans du milieu neuf. On fait subir à ce milieu ensemencé une pré-incubation de 60 minutes environ qui, si l'inoculum n'a pas été refroidi, abaisse le $p H$ de 8,0 à 6,5 : on se place ainsi en pleine phase logarithmique de croissance (fig. 1), et à la limite de la zone où les variations de $p \mathrm{H}$ sont les plus importantes dans le milieu de dosage (fig. 3).

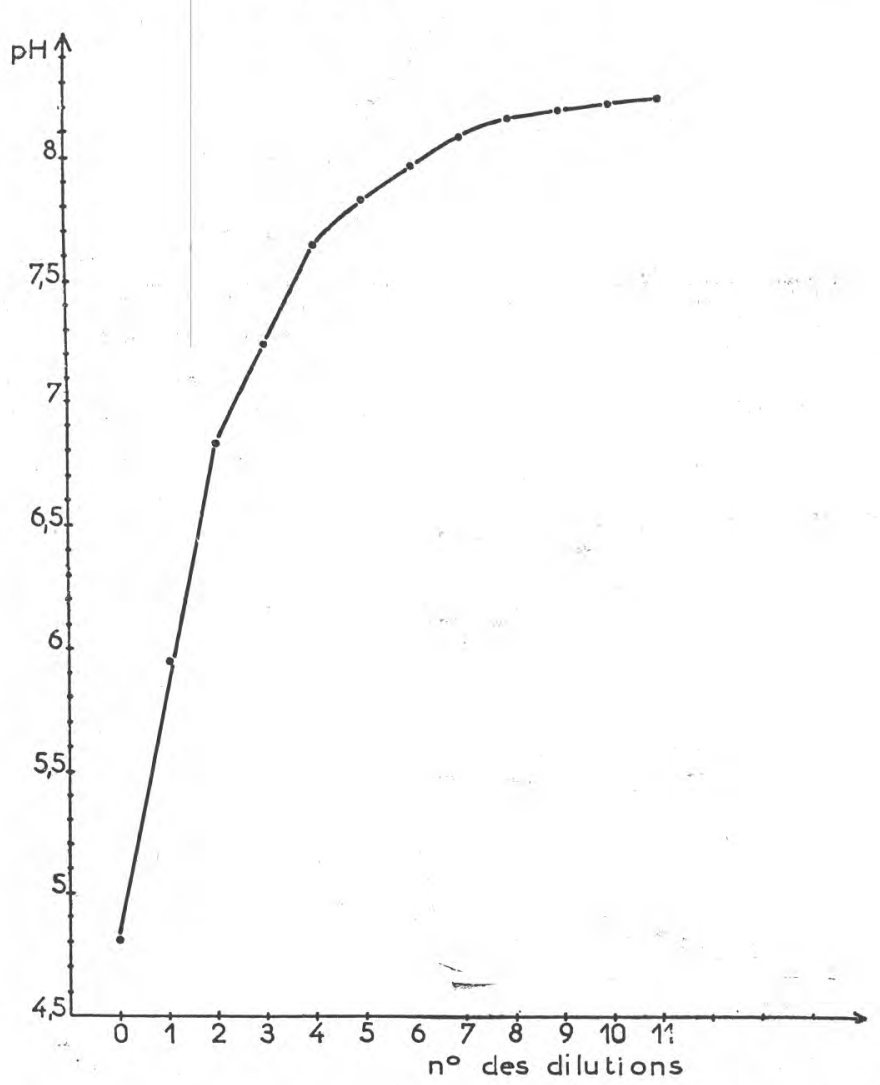

Fig. 3. - Variations du $p \mathrm{H}$ en fonction des quantités d'acide lactique ajoutées au milieu de GUITTONNEAU non ensemencé. La dilution notée 0 correspond à $105 \mu$ grammes d'acide lactique par millilitre du milieu de culture. Les dilutions suivantes sont entre elles dans le rapport 2/3.

\section{Dilution du lactosérum contenant la nisine}

Avant la fin de la pré-incubation, on prépare les dilutions du lactosérum contenant la nisine. Une première dilution est faite à la 
pipette au $1 / 10^{\mathrm{e}}$ ou au $1 / 20^{\mathrm{e}}$ selon la concentration supposée en nisine, les dilutions suivantes à la seringue selon la technique décrite par Berridge [4], [7]. Tous les tubes reçoivent 1,5 ml de lactosérum dilué. La dilution no 0 correspond à la dilution au $1 / 30^{\mathrm{e}}$ ou $1 / 60^{\mathrm{e}} \mathrm{du}$ lactosérum, suivant la dilution de base, la dilution n⿳0 1 est dans le rapport $2 / 3$ avec celle-ci; de même pour les autres dilutions. Le diluant est de l'eau stérile.

Chaque série de dilutions est faite en double ou en triple et encadrée de deux témoins : le "blane " indiquant le $p \mathrm{H}$ du milieu au moment où l'incubation proprement dite commence, c'est-à-dire à la fin de la période de pré-incubation, le témoin " développement " indiquant le $p \mathrm{H}$ de la culture sans antibiotique, à la fin de l'incubation.

\section{Répartition du milieu de culture}

La pré-incubation terminée, on répartit le milieu à raison de 4 millilitres par tube au moyen d'un répartiteur (P. K. B. Paris) le plus rapidement possible : 2 minutes pour 100 tubes, en prenant soin de ne pas laisser refroidir le milieu. Les "blancs» sont, par contre, refroidis aussitôt à $15^{\circ}$.

\section{Incubation et arrêt du développement}

On incube 30 minutes environ, à $68^{\circ}$, jusqu'à ce que le $p H \mathrm{H}$ u témoin "développement" atteigne 5,5. Pour arrêter le développement des bactéries, il suffit de refroidir les tubes rapidement à $15^{\circ}$, température à laquelle le $p \mathrm{H}$ reste stable durant les heures qui suivent.

\section{Mesure du $p \mathrm{H}$}

Les $p \mathrm{H}$ sont mesurés à l'électrode de verre, à 0,02 unités $p H$ près, dans les tubes de culture eux-mêmes. On effectue ainsi une centaine de mesures en une heure.

\section{Expression des résultats}

Nos essais étant essentiellement comparatifs, nous n'avons pas rapporté les doses de nisine à l'unité standard définie par MatTick et HIRSCH [1] et par BERRIDGE[8]. Nos résultats sont illustrés par des graphiques portant les $p H$ en ordonnée et les numéros des dilutions en abscisse : on compare la teneur en nisine des divers lactosérums en comparant les dilutions de ces lactosérums qui correspondent à une même valeur du $p \mathrm{H}$.

\section{RÉSULTATS}

\section{Allure des courbes de dosage}

La figure 4 montre l'allure des courbes que l'on peut obtenir à partir de divers lactosérums contenant de la nisine, suivant le 
nombre de dilutions. Avec peu de dilutions, 5 ou 6, la courbe est une droite avec une bonne approximation, et la relation entre le $p \mathrm{H}$ et la concentration c en nisine peut s'écrire :

$$
p \mathrm{H}=\mathrm{k} \log . \mathrm{c}
$$

puisque les valeurs portées en abscisse sont proportionnelles au logarithme des concentrations en nisine. Mais lorsqu'on augmente le nombre des dilutions, on constate que la courbe obtenue peut se décomposer en plusieurs segments de droite, de pentes différentes : deux segments et même trois (fig. 4 B) si le nombre de dilutions est suffisant et si le temps d'incubation est assez long pour que l'action de l'inhibiteur se manifeste aux dilutions les plus poussées.

\section{Comparaison, à partir des courbes de dosage, du taux en nisine de lactosérums différents}

Comparons les courbes $\mathrm{A}$ et $\mathrm{B}$ de la figure 4. Le lactosérum est le même dans les deux cas, mais la dilution de base diffère : $1 / 10^{\mathrm{e}}$ dans le cas de la courbe $A, 1 / 20^{\circ}$ dans le cas de la courbe $B$. Ceci revient à comparer deux lactosérums différents dont l'un contient deux fois plus de nisine que l'autre. Comment, à partir des courbes expérimentales, retrouver ce résultat ?

Evaluons l'écart $\Delta x$ des abscisses $x^{1}$ et $x^{2}$ (fig. 4 B) correspondant à la même valeur $6,52 \mathrm{du} p \mathrm{H}$. Cet écart étant proportionnél au logarithme des concentrations correspondantes $c^{1}$ et $c^{2}$ en nisine, on peut écrire :

d'où :

$$
\log c^{1}=\log c^{2}+\Delta x
$$

$$
\frac{c^{1}}{c^{2}}=10 \Delta x
$$

Le rapport des concentrations se calcule donc aisément à partir des données graphiques, compte tenu de l'échelle adoptée et du rapport des dilutions. Sur nos graphiques, 1 centimètre représente log. $3 / 2$ soit 0,176 .

$$
\begin{aligned}
& \Delta x=1,9 \mathrm{~cm} \\
& \Delta x=\log .2,16 \\
& \frac{c^{1}}{c^{2}}=2,16
\end{aligned}
$$

On en déduit que les dilutions de base des lactosérums sont dans la rapport 2,16 . Pour les valeurs 6,35 et 6,19 du $p H$

$$
\begin{aligned}
& \Delta x=2,1 \mathrm{~cm} \\
& \frac{c^{1}}{c^{2}}=2,34
\end{aligned}
$$

La valeur moyenne de ces trois rapports : $2,16-2,34-2,34$, soit 2,28 , donne une idée de l'approximation des résultats : en effet le 
rapport théorique des concentrations en nisine des deux lactosérums $\mathrm{A}$ et $\mathrm{B}$ est 2 , le rapport trouvé expérimentalement 2.28 , d'où :

$$
\text { Erreur } \%=\frac{2,28-2}{2} 100=14 \%
$$

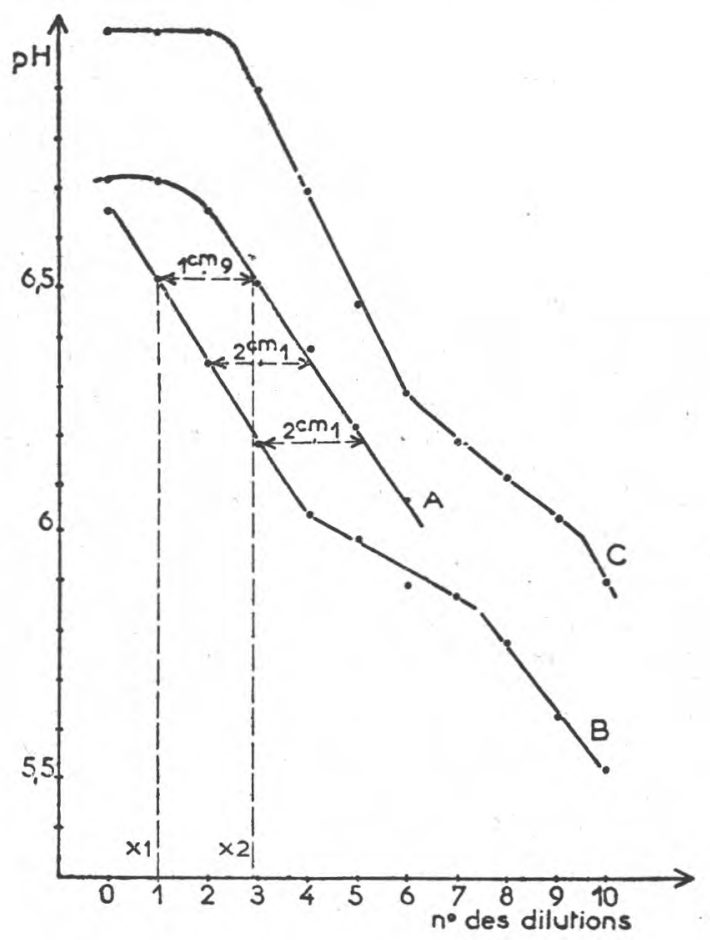

Fig. 4. - Valeurs du $p \mathrm{H}$ dans les différents tubes contenant les dilutions du lactosérum dont on veut doser la nisine après un temps d'incubation déterminé. Les dilutions successives numérotées de 0 à 10 sont entre elles dans le rapport $2 / 3$.

Les indications portées sur le graphique se rapportent aux pages 384 et $385 \mathrm{du}$ texte.

Hirsch [2], utilisant une méthode turbidimétrique, obtient une approximation de 10 à $15 \%$, alors que la méthode turbidimétrique de Berridge [7] permet une approximation de 5,9\% à $9 \%$.

\section{Influence des conditions expérimentales sur les résultats}

Pour justifier le mode opératoire que nous avons proposé, il est important de déterminer l'influence des divers facteurs expérimen- 
taux sur la dispersion des résultats obtenus, l'allure des courbes de dosage, et la stabilité de la nisine elle-même.

\section{Effet de la répartition en phase de latence du milieu ensemencé sur le taux de croissance dans les divers tubes}

Le tableau I montre les écarts notables que présentent entre eux, pour une même dilution, les $p \mathrm{H}$ de différentes séries de tubes lorsque le milieu ensemencé est réparti en phase de latence et non en phase logarithmique. Un tel résultat peut être rapproché, semblet-il, de l'auto-adaptation des populations bactériennes signalée par WRIGHT [10] : dans notre essai, on peut admettre que chaque tube constitue une population bactérienne qui a son taux de croissance propre responsable des écarts de $p \mathrm{H}$ avec les tubes voisins.

Ce fait souligne la nécessité, pour avoir des résultats homogènes, d'éviter l'apparition d'une phase de latence dans le milieu préincubé, au moment de la répartition.

\section{TABLEAU I}

INFLUENCE DE LA RÉPARTITION EN PHASE DE LATENGE DU MILIEU ENSEMENCÉ SUR LA DISPERSION DES VALEURS EXPÉRIMENTALES DU $p H$

\begin{tabular}{c|c|c}
\hline \hline $\begin{array}{c}\text { Temps d'incubation } \\
\text { en minutes }\end{array}$ & $\begin{array}{c}p H: \\
\text { moyenne de 10 tubes }\end{array}$ & $\begin{array}{c}\Delta p H: \text { écart maximum } \\
\text { par rapport à la moyenne }\end{array}$ \\
\cline { 2 - 3 } & & \\
30 & 8,05 & 0,01 \\
40 & 7,84 & 0,02 \\
45 & 7,75 & 0,05 \\
50 & 7,70 & 0,02 \\
55 & 7,66 & 0,02 \\
65 & 7,60 & 0,05 \\
80 & 7,50 & 0,03 \\
90 & 7,31 & 0,13 \\
100 & 7,19 & 0,02 \\
110 & 6,99 & 0,21 \\
115 & 6,68 & 0,11 \\
120 & 6,62 & 0,31 \\
130 & 6,41 & 0,10 \\
140 & 6,18 & 0,16 \\
150 & 6,02 & 0,27 \\
160 & 5,84 & 0,11 \\
170 & 5,70 & 0,05 \\
& 5,60 & 0,07 \\
\hline \hline
\end{tabular}




\section{Influence de la durée de pré-incubation}

La figure 5 montre que si l'on fait varier le $p H$ du "blane " par une pré-incubation dont la durée est plus ou moins longue, les courbes obtenues à partir d'un même lactosérum sont nettement distinctes. Lorsqu'on compare des lactosérums différents, il faut donc avoir soin de choisir la même durée de pré-incubation pour les différentes séries de dosage et la répartition du milieu préincubé doit être assez rapide pour que le $p H$ des "blancs» ne varie pas dans une trop large mesure.

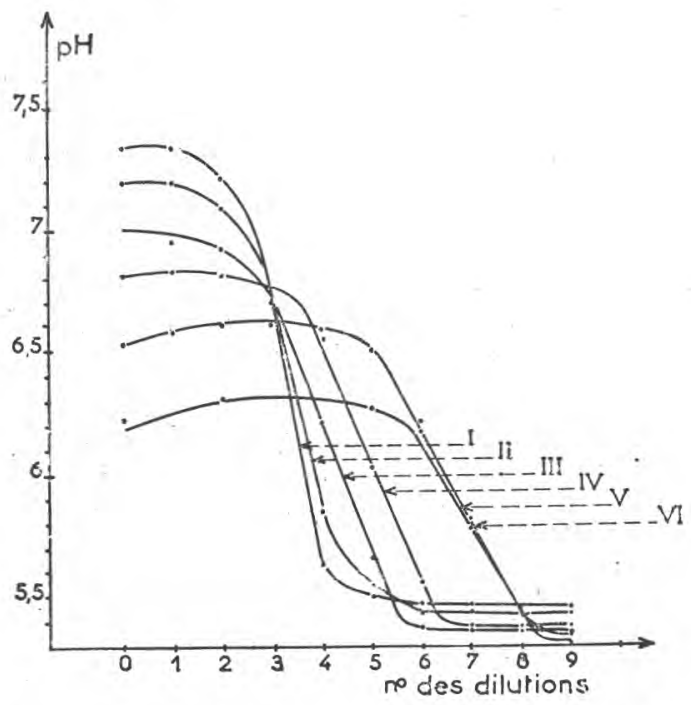

Fig. 5. - Influence du $p \mathrm{H}$ du «blanc» sur les valeurs correspondantes du $p H$ dans les différents tubes contenant des dilutions du lactosérum dont on veut doser la nisine. Courbe I : $p \mathrm{H}$ du "blane" = 7,34. - Courbe II: $p \mathrm{H} \mathrm{du}$ "blane " $=7,20$. - Courbe III : $p \mathrm{H} \mathrm{du}$ "blanc » = 7,04. - Courbe VI : $p \mathrm{H} \mathrm{du}$ "blane " $=6,83$. - Courbe $\mathrm{V}: p \mathrm{H} \mathrm{du}$ " blane " $=6,52$. - Courbe VI : $p \mathrm{H}$ du "blane $"=6,23$.

Cette condition restreint le nombre de dosages que l'on peut effectuer en même temps. Pour répartir le milieu pré-incubé dans 100 tubes il faut environ 2 minutes, pendant lesquelles le $p \mathrm{H} d u$ "blane " varie de $0,1 \pm 0,02$ (fig. 1). La figure 5 montre que cette variation est négligeable si l'on choisit la valeur 6,5 pour le $p H$ du "blanc " puisque, pour des $p \mathrm{H}$ du "blanc " compris entre 6,5 et 6,2 , les courbes de dosage sont très voisines les unes des autres. Or 100 tubes correspondent en moyenne à 10 dosages. Il est donc possible d'effectuer en même temps 10 dosages. 


\section{Influence de la durée d'incubation}

La figure 6 montre l'effet de la durée d'incubation sur la pente des segments correspondants des courbes de dosage. Si l'on veut les utiliser pour comparer les teneurs en nisine de divers lactosérums, il faut conserver un temps d'incubation constant, à 2 minutes près.

\section{TABLEAU II}

\section{INFLUENGE DE LA DURÉE D'INGUBATION SUR LA DISPERSION DES GHIFFRES EXPÉRIMENTAUX}

(1) 4 millilitres de milieu pré-incubé.

(2) 8 millilitres de milieu pré-incubé.

(3) Valeur du $p \mathrm{H}$ dans les tubes ne contenant pas de nisine à la fin de l'incubation.

(4) Valeur du $p \mathrm{H}$ du milieu à la fin de la pré-incubation.

\begin{tabular}{|c|c|c|c|c|}
\hline \multirow{2}{*}{$\mathrm{N}^{\circ}$ des dilutions } & \multicolumn{2}{|c|}{$\begin{array}{c}p \mathrm{H}: \\
\text { moyenne de } 3 \text { tubes }\end{array}$} & \multicolumn{2}{|c|}{$\begin{array}{l}\Delta p \mathrm{H} \text { : écart maximum } \\
\text { par rapport à la moyenne }\end{array}$} \\
\hline & $\begin{array}{l}30 \text { minutes (1) } \\
\text { d'incubation }\end{array}$ & $\begin{array}{c}60 \text { minutes }(2) \\
\text { d'incubation }\end{array}$ & 30 minutes & 60 minutes \\
\hline $0 \ldots \ldots \ldots \ldots \ldots$ & 6,60 & 7,62 & 0,02 & 0,03 \\
\hline $1 \ldots \ldots \ldots \ldots$ & 6,57 & 7,64 & 0,01 & 0,02 \\
\hline $2 \ldots \ldots \ldots \ldots \ldots$ & 6,50 & 7,58 & 0,02 & 0,02 \\
\hline $3 \ldots \ldots \ldots \ldots \ldots$ & 6,41 & 7,26 & 0,01 & 0,04 \\
\hline $4 \ldots \ldots \ldots \ldots \ldots$ & 6,32 & 6,23 & 0,02 & 0,17 \\
\hline $5 \ldots \ldots \ldots \ldots \ldots$ & 6,26 & 5,50 & 0,00 & 0,03 \\
\hline $6 \ldots \ldots \ldots \ldots$ & 6,21 & 5,50 & 0,01 & 0,01 \\
\hline $\begin{array}{l}\text { Témoin "dévelop- } \\
\text { pement " (3) . }\end{array}$ & 5,97 & 5,18 & 0,01 & 0,01 \\
\hline$" B l a n c "(4) \ldots$. & 6,60 & 7,60 & 0,01 & 0,01 \\
\hline
\end{tabular}

A-t-on intérêt à prolonger le temps d'incubation ? Le tableau II montre que, lorsque l'écart entre deux $p \mathrm{H}$ successifs d'une même série de dilutions augmente, par suite d'une incubation prolongée, la dispersion des chiffres expérimentaux augmente aussi. Ce fait est peut-être à relier au phénomène d'auto-adaptation : dans les tubes qui contiennent la nisine, une phase de latence s'établit, du fait que les cellules intactes y sont moins nombreuses et se trouvent dans les conditions d'un milieu ensemencé réparti en phase de latence.

Par conséquent, on n'a pas intérêt à prolonger le temps d'incubation puisque la précision des résultats n'est pas améliorée et que, par ailleurs, on cherche à obtenir une réponse rapide. 


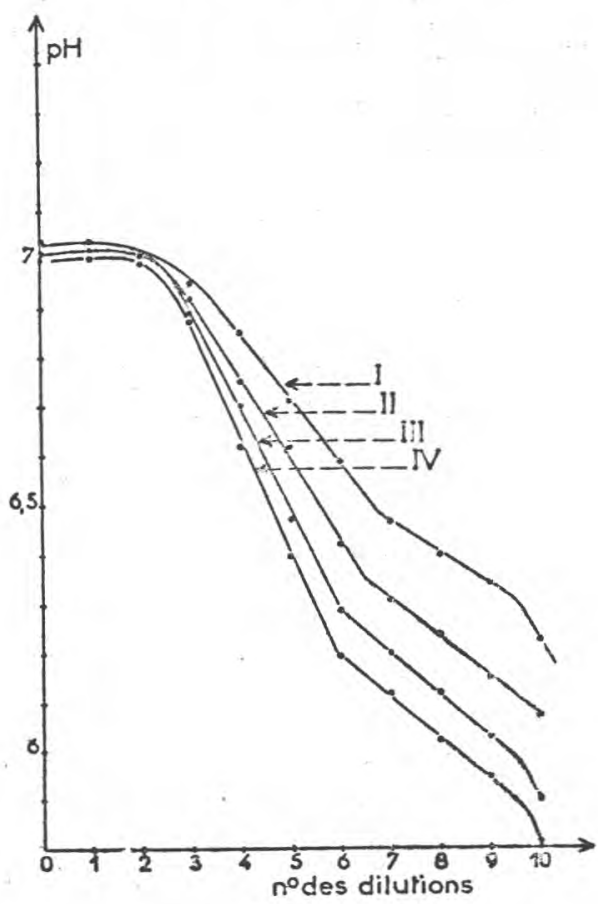

Fig. 6. - Influence du temps d'incubation sur les valeurs correspondantes du $p \mathrm{H}$ dans les différents tubes contenant les dilutions du lactosérum dont on veut doser la nisine. Courbe I : 30 minutes d'incubation. - Courbe II : 40 minutes d'incubation. - Courbe III : 50 minutes d'incubation. - Courbe IV : 60 minutes d'incubation.

\section{Influence du volume de milieu pré-incubé réparti dans chaque tube}

La figure 7 montre que, lorsqu'on répartit des volumes variables de milieu pré-incubé dans chaque tube, les courbes de dosage sont nettement distinctes. Pour qu'elles soient comparables il faut done s'assurer que la mesure du volume réparti est effectuée avec une précision suffisante. La figure 7 montre qu'une variation de volume de 2 millilitres correspond, dans la partie logarithmique des courbes, à une variation de 0,1 unité $p \mathrm{H}$. Une variation de $0,4 \mathrm{ml}$, qui correspond par conséquent à une variation de 0,02 unité $p H$ seulement, entrâne une erreur négligeable sur la valeur du $p \mathrm{H}$. Le répartiteur que nous utilisons dans nos essais est suffisamment précis puisqu'il répartit 4 millilitres avec $5 \%$ d'erreur soit à $0,2 \mathrm{ml}$ près.

En ce qui concerne le volume de milieu pré-incubé à distribuer dans chaque tube, on a intérêt à le choisir aussi faible que possible. On réduit ainsi la dilution supplémentaire du lactosérum introduite 


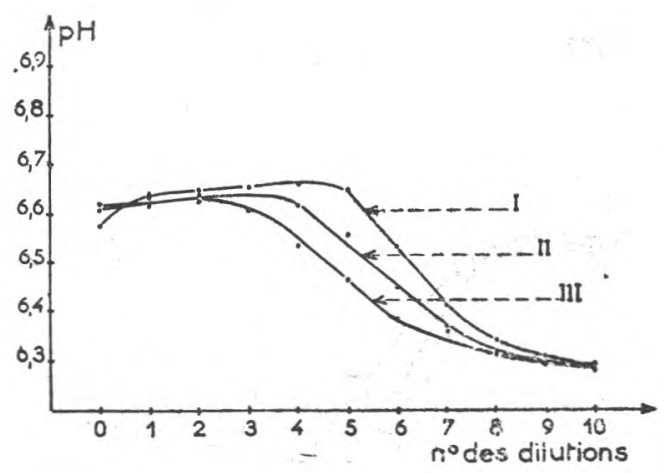

Fig. 7. - Influence du volume de milieu pré-incubé réparti sur les valeurs correspondantes du $p \mathrm{H}$ dans les différents tubes contenant les dilutions de lactosérum dont on veut doser la nisine. Courbe I : volume de milieu pré-incubé réparti : 4 millilitres. - Courbe II : volume de milieu préincubé réparti : 6 millilitres. - Courbe III : volume de milieu pré-incubé réparti : 8 millilitres.

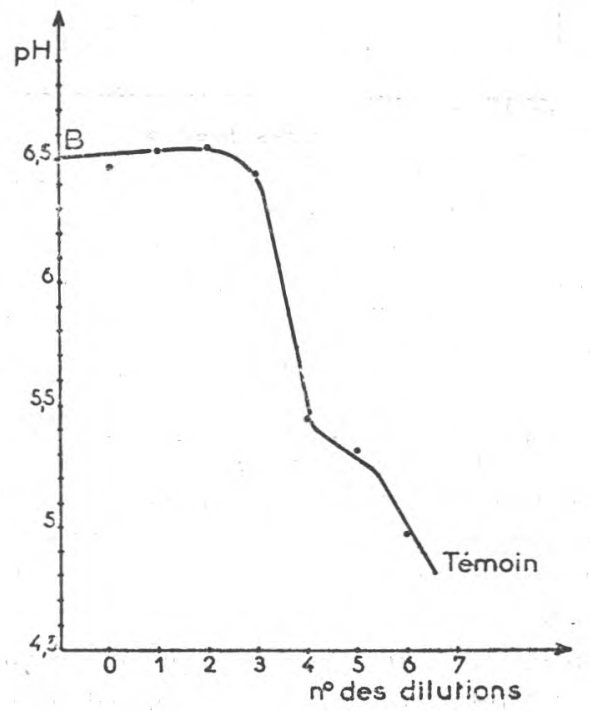

Fig. 8. - Valeurs du $p H$ dans les différents tubes contenant les dilutions du lactosérum dont on veut doser la nisine, en utilisant comme organismetest Lactobacillus helveticus, souche $\mathrm{E}_{4}$. Incubation à $45^{\circ}$ pendant $1 \mathrm{~h} .40$.

par le milieu pré-incubé, la quantité de milieu à répartir et la durée de la répartition.

Cependant, l'expérience montre que si l'on distribue moins de 4 millilitres de milieu pré-incubé par tube la dispersion des chiffres 
expérimentaux augmente beaucoup, sans doute à cause de la dilution des cellules de l'organisme-test dans la dilution du lactosérum, qui provoque l'apparition d'une phase de latence.

Ce volume de 4 millilitres de milieu pré-incubé ajouté à chaque tube contenant déjà la dilution du lactosérum, soit 1,5 $\mathrm{ml}$, nous a paru le plus favorable pour obtenir des résultats précis avec le minimum de milieu.

\section{Stabilité de la nisine dans les conditions du dosage}

Hirsh [11] a montré que la stabilité de la nisine diminue beaucoup de $p \mathrm{H} 4$ à $p \mathrm{H} 8$, c'est-à-dire dans la zone de $p \mathrm{H}$ où nous nous sommes placés.

Le tableau III illustre cette influence du $p \mathrm{H}$ sur la destruction de la nisine dans les dilutions du lactosérum : celles-ci sont chauffées 1 heure à $68^{\circ}$, en présence de $2,5 \mathrm{ml}$ de milieu non ensemencé, ajusté au $p \mathrm{H}$ voulu. Après ce pré-chauffage, on dose la nisine non détruite en comparant avec une série de dilutions témoins.

On voit que, lorsque le pré-chauffage a lieu aux $p H \quad 7,32,7,14$, $6,80,6,48$, la proportion de nisine détruite dans les dilutions de lactosérum est d'environ $1 / 3$ puisque le tube contenant la dilution 4 , dans la série ayant subi un pré-chauffage, a le même $p H$ que celui contenant la dilution 5 de la série témoin. A $p \mathrm{H} 6,98$, le tableau III montre que la proportion de nisine détruite est plus élevée, le tube contenant la dilution 3 dans la série pré-chauffée ayant le même $p H$ que celui contenant la dilution 5 de la série témoin. Ce maximum de destruction à $p \mathrm{H}$ n'est cependant pas trouvé par Hirsch [11] qui note au contraire un minimum de destruction de la nisine vers ce $p H$.

Cette destruction de la nisine est rapide, comme l'indique le tableau IV : lorsque les dilutions de lactosérum sont chauffées au même $p H$ durant des temps variables, on constate que la destruction de la nisine se manifeste déjà a près 5 minutes de pré-chauffage, mais qu'elle augmente peu pour des durées de pré-chauffage plus longues.

Ces résultats montrent que la nisine peut être détruite dans les conditions de $p \mathrm{H}$ et de température du dosage. Aussi la répartition du milieu pré-incubé doit-elle suivre immédiatement l'introduction des tubes contenant les dilutions du lactosérum dans le bain-marie à $68^{\circ}$.

\section{DISCUSSION}

L'utilisation de Thermobacillus tarbellicus comme organisme-test pour le dosage de la nisine présente des avantages incontestables. Grâce à la grande activité enzymatique de cette bactérie thermophile, la méthode" décrite prend place parmi les méthodes rapides 
et précises, celle de BerRIDGe [7] par exemple, L'incubation à $68^{\circ}$ permet d'alléger considérablement le dosage, du fait qu'il n'est pas nécessaire d'employer un milieu stérile ni de manipuler dans des conditions d'asepsie rigoureuse, avec un matériel stérile. De plus l'extrême simplicité du milieu, tant dans sa composition que dans sa préparation, représente un avantage important par rapport aux milieux plus complexes nécessaires à la croissance d'organismestest plus exigeants.

Les inconvénients de la méthode se retrouvent, pour la plupart, dans les autres procédés : nécessité de faire de nombreuses dilutions, difficulté d'avoir au moment voulu une culture convenablement pré-incubée. D'autres inconvénients sont inhérents aux caractères

TABLEAU III

INFLUENCE DU PRÉ-CHAUFFAGE A $p$ H VARIABLE SUR LA DESTRUCTION DE LA NISINE DANS LES DILUTIONS DE LACTOSÉRUM

Volume du milieu pré-incubé : 6 millilitres.

Les valeurs portées en regard des numéros des dilutions représentent les $p \mathrm{H}$ dans les différents tubes.

\begin{tabular}{|c|c|c|c|c|c|c|c|c|c|c|}
\hline \multirow{2}{*}{$\begin{array}{c}p \mathrm{H} \text { de pré- } \\
\text { chauffage }\end{array}$} & \multicolumn{2}{|c|}{7,32} & \multicolumn{2}{|c|}{7,14} & \multicolumn{2}{|c|}{6,98} & \multicolumn{2}{|c|}{6,80} & \multicolumn{2}{|c|}{6,48} \\
\hline & $\begin{array}{l}\text { Té- } \\
\text { moin }\end{array}$ & $\begin{array}{l}\text { Pré- } \\
\text { chauffé }\end{array}$ & $\begin{array}{l}\text { Té- } \\
\text { moin }\end{array}$ & $\begin{array}{l}\text { Pré- } \\
\text { chauffé }\end{array}$ & $\begin{array}{l}\text { Té- } \\
\text { moin }\end{array}$ & $\begin{array}{c}\text { Pré- } \\
\text { chauffé }\end{array}$ & $\begin{array}{l}\text { Té- } \\
\text { moiu }\end{array}$ & $\begin{array}{c}\text { Pré- } \\
\text { chauffé }\end{array}$ & $\begin{array}{l}\text { Té- } \\
\text { moin }\end{array}$ & $\begin{array}{c}\text { Pré- } \\
\text { chauffé }\end{array}$ \\
\hline $2 \ldots \ldots \ldots$ & 7,11 & 6,95 & 7,06 & 7,01 & 7,03 & 6,71 & 7,01 & 7,00 & - & 6,97 \\
\hline $3 \ldots \ldots \ldots$ & 6,95 & 6,51 & 6,94 & 6,65 & 6,97 & 6,19 & 6,98 & 6,82 & - & 6,68 \\
\hline $4 \ldots \ldots \ldots$ & 6,45 & 5,91 & 6,61 & 6,10 & 6,64 & 5,82 & 6,82 & 6,28 & - & 6,24 \\
\hline $5 \ldots \ldots \ldots$ & 5,92 & 5,68 & 6,10 & 5,74 & 6,09 & 5,71 & 6,26 & 5,92 & 6,23 & 5,87 \\
\hline $6 \ldots \ldots \ldots$ & 5,73 & 5,59 & 5,79 & 5,65 & 5,80 & 5,65 & 5,88 & 5,76 & 5,94 & 5,82 \\
\hline $7 \ldots \ldots \ldots$ & 5,66 & 5,56 & 5,67 & 5,56 & 5,68 & 5,65 & 5,73 & 5,70 & 5,82 & 5,72 \\
\hline $8 \ldots \ldots \ldots$ & 5,62 & 5,53 & 5,63 & 5,58 & 5,65 & 5,62 & 5,68 & 5,67 & 5,79 & 5,73 \\
\hline
\end{tabular}

culturaux de l'organisme-test utilisé, principalement l'apparition d'une phase de latence importante lorsque le milieu de culture est refroidi ou lorsque la dose d'inoculation eșt trop faible.

On peut objecter que dans les conditions de température et de $p \mathrm{H}$ du dosage la destruction de la nisine fausse les résultats : cette destruction est indiscutable (tableaux III et IV), mais peut-on affirmer qu'elle intervient effectivement dans le dosage ? Il est bien possible que la nisine agisse avant toute destruction dûe au chauffage dans les conditions de $p \mathrm{H}$ où l'on se trouve placé.

On a vu (fig. 5) l'influence du $p \mathbf{H}$ du "blanc» sur les résultats : elle n'est pas identique à l'effet du chauffage sur la stabilité de la 
nisine. En effet, alors que la destruction de la nisine est la même à $p \mathrm{H} 7,32$ et à $p H$ 6,48 (tableau III), la concentration apparente de la nisine diminue constamment (fig. 5) lorsque le $p \mathrm{H}$ du blane varie de 7,32 à 6,23 ; il faut done penser que d'autres facteurs interviennent pour expliquer cet effet $\mathrm{du} p \mathrm{H}$ du «blanc » sur les

\section{TABLEAU IV}

\section{DESTRUCTION DE LA NISINE DANS LES DILUTIONS DE LACTOSÉRUM EN FONCTION DU TEMPS DE PRÉ-GHAUFFAGE, EN PRÉSENCE DE 2,5 ML DE MILIEU NON ENSEMENGE A $p$ H 6,6}

Volume du milieu pré-incubé réparti : 6 millilitres.

Les valeurs portées en regard des numéros des dilutions représentent les $p H$ dans les différents tubes.

\begin{tabular}{|c|c|c|c|c|c|c|c|c|c|c|}
\hline \multirow{2}{*}{$\begin{array}{c}\mathrm{N}^{\circ} \text { des } \\
\text { dilutions }\end{array}$} & \multicolumn{2}{|c|}{5 minutes } & \multicolumn{2}{|c|}{15 minutes } & \multicolumn{2}{|c|}{30 minutes } & \multicolumn{2}{|c|}{45 minutes } & \multicolumn{2}{|c|}{60 minutes } \\
\hline & $\begin{array}{l}\text { Té. } \\
\text { moin }\end{array}$ & $\begin{array}{l}\text { Pré- } \\
\text { chauffé }\end{array}$ & $\begin{array}{l}\text { Té. } \\
\text { moin }\end{array}$ & $\begin{array}{c}\text { Pré- } \\
\text { chauffé }\end{array}$ & $\begin{array}{l}\text { Té- } \\
\text { moin }\end{array}$ & $\begin{array}{c}\text { Pré- } \\
\text { chauffé }\end{array}$ & $\begin{array}{l}\text { Té- } \\
\text { moin }\end{array}$ & $\begin{array}{l}\text { Pré- } \\
\text { chauffé }\end{array}$ & $\begin{array}{l}\text { Té. } \\
\text { moin }\end{array}$ & $\begin{array}{l}\text { Pré- } \\
\text { chauffé }\end{array}$ \\
\hline $2 \ldots \ldots \ldots$ & 6,68 & 6,59 & 6,62 & 6,57 & 6,62 & 6,52 & 6,59 & 6,51 & 6,58 & 6,49 \\
\hline 3. & 6,55 & 6,44 & 6,50 & 6,46 & 6,47 & 6,40 & 6,50 & 6,40 & 6,45 & 6,35 \\
\hline $4 \ldots \ldots \ldots$ & 6,34 & 6,10 & 6,35 & 6,17 & 6,33 & 6,10 & 6,38 & 6,08 & 6,33 & 5,97 \\
\hline $5 \ldots \ldots \ldots$ & 5,73 & 5,58 & 5,87 & 5,60 & 5,98 & 5,57 & 6,05 & 5,59 & 5,90 & 5,58 \\
\hline $6 \ldots \ldots \ldots$ & 5,66 & 5,61 & 5,57 & 5,59 & 5,58 & 5,58 & 5,58 & 5,60 & - & 5,56 \\
\hline $7 \ldots \ldots$ & 5,60 & 5,61 & 5,60 & 5,61 & 5,59 & 5,59 & 5,57 & 5,61 & 5,60 & 5,56 \\
\hline
\end{tabular}

résultats, par exemple l'âge moyen des cellules qui modifierait leur sensibilité vis-à-vis de la nisine, ou encore le mode d'action de la nisine qui serait étroitement dépendant du $p \mathrm{H}$ du milieu.

D'autre part nous avons vu que les courbes de dosage pouvaient se décomposer en segments de droite à pentes différentes, dans des conditions déterminées. La figure 3 montre que ces changements de pente ne sont pas dûs au pouvoir tampon du milieu. BERRIDGE [7] a signalé de telles irrégularités de pente dans les courbes de dosage, qu'il interprète par la présence de plusieurs facteurs antibiotiques. En effet, on peut penser que l'organisme-test réagit différemment à ces facteurs antibiotiques : l'un agirait aux faibles dilutions, un autre aux fortes dilutions, un troisième aux dilutions intermédiaires, ou bien deux facteurs seulement interviendraient, présentant une interaction aux dilutions intermédiaires. BERRIDGE [12] a d'ailleurs séparé 5 nisines différentes : A, B, C, D, et E, produites par Streptococcus lactis. Il est intéressant de rapprocher ces résultats de ceux signalés par Auclair et Hirsch [13] avec les lacténines. Nous avons nous-même obtenu des résultats analogues avec un autre organisme- 
test, Lactobacillus helveticus: en suivant l'évolution du $p \mathrm{H}$ en fonction des dilutions du lactosérum contenant la nisine, on constate des changements de pente reproductibles dans la courbe de dosage (fig. 8).

Quoiqu'il en soit, l'absence d'une réponse parfaitement linéaire pour l'ensemble des dilutions du lactosérum contenant la nisine complique le problème de l'expression des résultats en unités standard, et soulève également le problème des autres antibiotiques produits par les différentes souches de Streptococcus lactis.

\section{RÉSUMÉ}

Une bactérie thermophile, Thermobacillus tarbellicus, saccharolytique, dont l'optimum de croissance est $68^{\circ}$, a été utilisée pour un dosage rapide de la nisine produite par Streptococcus lactis. Elle est cultivée sur un milieu simple, à base de peptone et de saccharose, qu'il n'est pas nécessaire d'autoclaver, avec un matériel non stérile et sans précautions spéciales d'asepsie dans les manipulations. On suit les variations du $p H$ du milieu de culture en fonction des concentrations en nisine du lactosérum.

Les courbes obtenues présentent, dans des conditions qui sont précisées, des changements de pente reproductibles suggérant la présence de plusieurs facteurs antibiotiques dans les lactosérums étudiés.

L'influence de certaines conditions expérimentales sur les résultats du dosage est envisagée : influence de la répartition en phase de latence du milieu ensemencé, de la durée de pré-incubation, de la durée d'incubation, du volume de milieu pré-incubé réparti dans chaque tube. Enfin la stabilité de la nisine dans les conditions du dosage est étudiée.

Nous exprimons notre profonde reconnaissance à M. Mocquot et à M. Chevalien pour l'aide et les conseils qu'ils nous ont donnés au cours de ce travail.

\section{RÉFÉRENCES BIBLIOGRAPHIQUES}

[1] A. T. R. Matrick and A. Hirsch. Further observations on an inhibitory substance (nisin) from lactic streptococei. Lancet, July ii, $5,1947$.

[2] A. Hrrsch. The assay of the antibiotic nisin. Journal gen. Microbiol., 4, 70,1950 .

[3] R. Friedmann and S. A. Beach. New methods of assay for the antibiotic nisin. Journal gen. Microbiol., 5, v, 1951.

[4] N.J. Berridge and J. Barrett. A rapid turbidimetric method for the assay of antibiotics. Nature, 167, 448, 1951. 
[5] R. Friedmann and C. Epstein. The assay of the antibiotic nisin by means of a reductase (resazurin) test. Journal gen. Mierobiol., 5, $830,1951$.

[6] S. A. BEACH. An agar diffusion method for the antibiotic nisin. Journal gen. Microbiol., 6, 60, 1952.

[7] N. J. Berridee and J. Barrett. A rapid method for the turbidimetric assay of antibiotics. Journal gen. Microbiol., 6, 14, 1952.

[8] N. J. Berridge. Preparation of the antibiotic nisin. Biochem. Journal, $45,486,1949$.

[9] G. Guitronneau. Sur un bacille sporulé thermophile fonctionnant comme ferment lactique. C.R. Ac. Sc., 187, 69, 1928.

[10] B. E. Wright. Auto-adaptation : a new phenomenon observed in a bacterial population. Journal Bact., 66, 407, 1953.

[11] A. Hirsch. Growth and nisin production of a strain of Streptococcus lactis. Journal gen. Mierobial., 5, 208, 1951.

[12] N. J. Berridge, G. G. F. Newton and E. P. Abraham. Purification and nature of the antibiotic nisin. Biochem. Journal, 52, 529, 1952.

[13] J. E. AUCLAIR and A. Hirsch. The inhibition of microorganisms by raw milk. I. The occurrence of inhibitory and stimulatory phenomena. Methods of estimation. Journal Dairy Res., 20; 45, 1953.

\section{CONDITIONS A REMPLIR \\ PAR LES PIPETTES A LAIT POUR BUTYROMÉTRIE (1) \\ par \\ JEAN PIEN}

A l'heure où l'on se préoccupe de plus en plus de normaliser les techniques et les appareils utilisés dans l'analyse du lait, il convient de se demander ce que devraient être les caractéristiques des pipettes à lait et notamment des pipettes destinées au dosage de la matière grasse par la méthode Gerber.

Ce souci est d'autant plus impérieux que les incertitudes existant encore actuellement quant au volume de lait mis en cuvre (incertitudes résultant de pipettes mal adaptées au but poursuivi ou de techniques de pipetage incorrectes) sont l'une des causes principales du défaut de fidélité quelquefois reproché à la méthode Gerber. Nous avons la conviction que si ce point de la méthode était amélioré (en même temps que les conditions de la lecture du volume de la colonne grasse) la méthode acidobutyrométrique selon Gerber pourrait devenir aussi fidèle et aussi précise que les meilleures méthodes pondérales de laboratoires (2).

(1) Communication au XIVe Congrès International de Laiterie. Rome, 1956.

(2) J. Pien. L'avenir de la méthode Gerber. C. R. XIVe Congrès International de Laiterie, Rome 1956, dans Le Lait, 37, p. 256.1957. 